\title{
The Challenges/Issues Faced by Stakeholders of Agri Business Incubation Centres
}

\author{
Kadire Preethika $^{1}$, D. Srinivasa Reddy ${ }^{1}$, P. Radhika $^{1 *}$ and K. Supriya ${ }^{2}$ \\ ${ }^{1}$ School of Agribusiness Management, College of Agriculture, Rajendranagar, Professor \\ Jayashankar Telangana State Agriculture University, Hyderabad, Telangana, India \\ ${ }^{2}$ Department of Mathematics and Statistics, College of Agriculture, Rajendranagar, \\ Professor Jayashankar Telangana, India \\ *Corresponding author
}

\section{A B S T R A C T}

\section{Keywords}

Stakeholders, Agri business, Incubation centres, New products

Article Info

Accepted:

22 July 2020

Available Online:

10 August 2020
Entrepreneurship development in agriculture became the major agenda for the government of India. It is very important to recognise the potential by putting innovations into practice by development of new products and services. For this purpose, Agri Business Incubation centres concept came into the practice in agri and allied sectors. Agri Business Incubation centres provided the services to encourage the start-up ventures, accelerate the business ideas towards sustainable ventures, to support the start-ups by funding etc. During the process of incubation, stakeholders were facing different challenges/issues which hindering the performance of the incubation centres. The present paper outlines the different challenges faced by the stakeholders in Agri Business Incubation centres.

\section{Introduction}

Agriculture plays a critical role in Indian economy. This is one of the riskiest and important sectors to be employed as it is highly dependent on uncontrollable factors like weather, topographical factors and market fluctuations. Modern techniques and methods will surely take agriculture to next level and ease the burden of farmers. Transformation of agriculture to the agribusiness is one of the important strategies to uplift the farmers, where enterprising the farmers practices in profitable way.

For the expansion of agriculture ecosystem that links farmers and markets, entrepreneurship and agribusiness ventures need to be promoted. It enables adapting the agro-technologies from the research stations to local conditions. For this purpose, to develop entrepreneurship in agri and allied 
sectors is the crucial step to be taken for further improvement.

Business incubation has been globally recognized as a crucial mechanism for supporting entrepreneurship through a welldesigned venture creation process. Start-up companies face many challenges from the idea generation stage to establishing as a sustainable company. Many companies look for a support to mentor through their journey, such as accelerators and business incubators.

Entrepreneurship development is the major agenda for the government of India; this is due to fact that most of the agri value chain has the problems of hindering the efficient agriculture and farmer's welfare. The Government of India along with Department of Science and Technology promotes the growth of the start-ups in the country. It is crucial to recognize the potential by putting the innovation into practices for development of new products, services that add value to the products. The goal of the Agri Business Incubation centres is to develop and commercialize the innovative products, technologies and services to improve the efficiency in agri and allied supply chains. ABI represents a new ways to promote enterprise development in agriculture and allied sectors. The pillars for high performance incubation are research and development, business planning, business development and access to capital.

The ICAR through National Agricultural Innovation Project (NAIP) has set up a network of ten Business Processing Development (BPD) units in 2012 in India (five in ICAR institutes and five in State Agriculture Universities) initially, followed by 12 more units in 2013. Later in 2013, under $12^{\text {th }}$ plan, the project on National Agriculture Innovation Fund (NAIF) addressed issues towards innovation and incubation by supporting Agribusiness Incubation centres. Further, Ministry of Agriculture and Ministry of Rural Development, Government of India, has also taken initiation to establish Agribusiness Incubation Centres/ Rural Technology Parks in India. In the process, seven Agribusiness Incubation Centres were established by agricultural institutes / organisations at Hyderabad. There is a need to evaluate the Agri Business Incubation centres periodically, such that it reduces the gaps created between the incubators and incubatees. The reviewing helps the incubators in planning strategies, upgrading the technologies and providing qualitative \& quantitative services to the incubatees.

The present study is conducted to evaluate the Agri Business Incubation centres with the following objectives includes to study the different challenges faced by the incubatees during the process of incubation and also to study the different challenges faced by the incubation centres.

Akcomak (2009) in his paper on "Incubators as tools for entrepreneurship promotion in developing countries" conclude that there are many weaknesses in incubators of developing countries which include focus on the tangible services than intangible services, dependence on government, lack of management and qualified personnels lack of planning and creativeness in solving problems. Also expressed that successful incubators display a creative and innovative character of approaching the problems of tenant companies. Therefore, policy of incubators should be well-designed with the other policies for entrepreneurship promotion and economic development.

Tengeh and Choto (2015) in their paper on "The relevance and challenges of business incubators that support survivalist 
entrepreneurs" expressed that $55.1 \%$ of the respondents were benefited through incubation program, while $44.9 \%$ of the respondents were not benefited by attending the incubation program. They also concluded that Business incubators were facing challenges like lacking of funding, lack of support from the stakeholders, uncommitted clients ect. Amongst all the major challenge was lack of funding. Business Incubators face critical challenges which affect the longevity of their services. The challenges threaten the survival of the incubators, quality and quantity of services they provide.

Bagchi and Chaterjee (2017) in their paper on "Identification of gaps in performance of services provided to start-ups in agri-business incubation centres in India" attempted to identify the gaps in the performance of the services being provided by the incubation centres. The paper outlines the areas that incubation centres need to focus on to encourage growth of start-ups being incubated. In the social and agri-business incubation centres, maximum gaps are observed in services like marketing assistance to access market, training on managerial and legal issues and access to fund (grant, venture capital, angel investor etc.).

Meru and Struwig (2011) in their paper on "An evaluation of the entrepreneurs perception of Business-Incubation services in Kenya" explained that entrepreneurs have the great importance in the Business Incubation services, but the actual services received by the entrepreneurs would be less than expected services. From the study conducted in Kenya the researchers concluded that most of the business incubators focused on the need for profits rather than excellent service delivery.

Lose and Tengeh (2015) in their paper on "The sustainability and challenges of Business Incubators in the western cape province, South Africa" investigated about the challenges faced by Business Incubators. The study revealed that lack of sponsor ship, production space, advanced technological facilities and expansion into different areas which were found to be major challenges faced by business incubators.

Tietz et al., (2015) in their paper on "Business Incubators in Brazil: Main gaps to be explored by academic researchers", expressed that the Business Incubators have a very important role at the world entrepreneurial ecosystem. Through the support incubators are offering to the entrepreneurs reduce the mortality risk of startup companies and contribute to better performance of the country's economy. The results of their research shows that there are many gaps to be explored by academic researchers such as internal characteristics or the interrelationship between business incubators and triple helix (i.e., interactions between industry, university and government).

Etela and Onoja (2017) in their paper on "Incentivizing e-agriculture and Agribusiness Incubators for youth employment in Nigeria mentioned that the use of ICT and prompting establishment of functional agribusiness incubators in strategically selected universities in Nigeria is needed for attracting youth into agriculture for better employment generation in this sector. The paper has demonstrated that, there are challenges with the extent of youth employment in agriculture due to limited inclusion and lack of favourable environment for creating a sense of ownership by the youth in the agriculture value chain. To overcome these challenges, the policy makers recommended that agribusiness incubators should be promoted as vital linkage between universities and industry because they promote the training of industry-ready university graduates with adequate entrepreneurship orientation. They 
also proposed that university based scientists who develop viable technologies to drive successful agribusinesses should transfer promotion of the technology packages to the affiliated incubators. And they also proposed that moderate fee should be charged for products and services of the agribusiness incubators to ensure the sustainability even in the initial phase of donor sponsorship.

Srinivas et al., (2019) in their bulletin on "Fostering entrepreneurship through Incubation centres in NARES" mentioned that, Incubation centres play a very critical role to the success of start-ups and young entrepreneurs. A well structured incubation programme helps the startup from idea generation stage to setting up the business and most crucial funding support. The challenge faced by the incubators in India is finding good start-ups that solve the problems in the market or in value chain.

There is a large asymmetry has been created due to the difficulty in start-ups and incubators to price rightly for the value addition at an early stage of the enterprise. Incubators charge for the services it provides. The charges may be in the form of fees, equity or combination of both. If startup fails, there is no realization for the incubator. The issue is more complex in terms of fees. Most of the incubatees fail in paying the fees and incubator need to condone it. Government owned incubators have the problem in this model as the receivables increase in their balance sheet.

\section{Materials and Methods}

The study was conducted in Hyderabad district of Telangana state covering five Agri Business Incubation centres and 75 incubatees benefited through these incubation centres.

The study was conducted through structured questionnaires; due to the pandemic situation of COVID19, primary data was collected through Google questionnaires from respondents and secondary data was collected from websites, articles, reports etc.

\section{To study the challenges faced by incubatees} during the process of incubation:

Different challenges have been provided to know the perception of the beneficiaries in terms of which challenge is faced critically on the whole and it is calculated through ranking method in which total score of each challenge is calculated and ranked accordingly.

\section{Results and Discussion}

According to the given data, table 1 indicates the rank order preferences of challenges faced by the incubatees. Through the analysis it is summarized that, technology related challenges are ranked first and considered as a most critical challenge while infrastructure is given eighth rank and considered as a least faced challenge.

Apart from the above challenges, the incubatees also face the challenges like geographical area; where the tenant entrepreneurs or incubatees and incubators gets a gap, so that incubatees cannot have the access to the services.

Satisfaction of the incubatees towards the incubators is the other challenge, where incubatees gets disappointed with the services and loose the motivation which leads to inefficient output of the services. 
Table.1 Rank order preference of challenges faced by the incubates

\begin{tabular}{|l|c|c|}
\hline Challenges & Total Score & Rank \\
\hline Technology related & 591 & 1 \\
\hline High capacity investment & 435 & 2 \\
\hline Mentoring services & 386 & 3 \\
\hline Strategies related & 345 & 4 \\
\hline R\&D & 330 & 5 \\
\hline Legal & 315 & 6 \\
\hline IPR issues & 278 & 7 \\
\hline Infrastructure & 168 & 8 \\
\hline
\end{tabular}

Table. 2 The challenges faced by Agribusiness Incubation centres

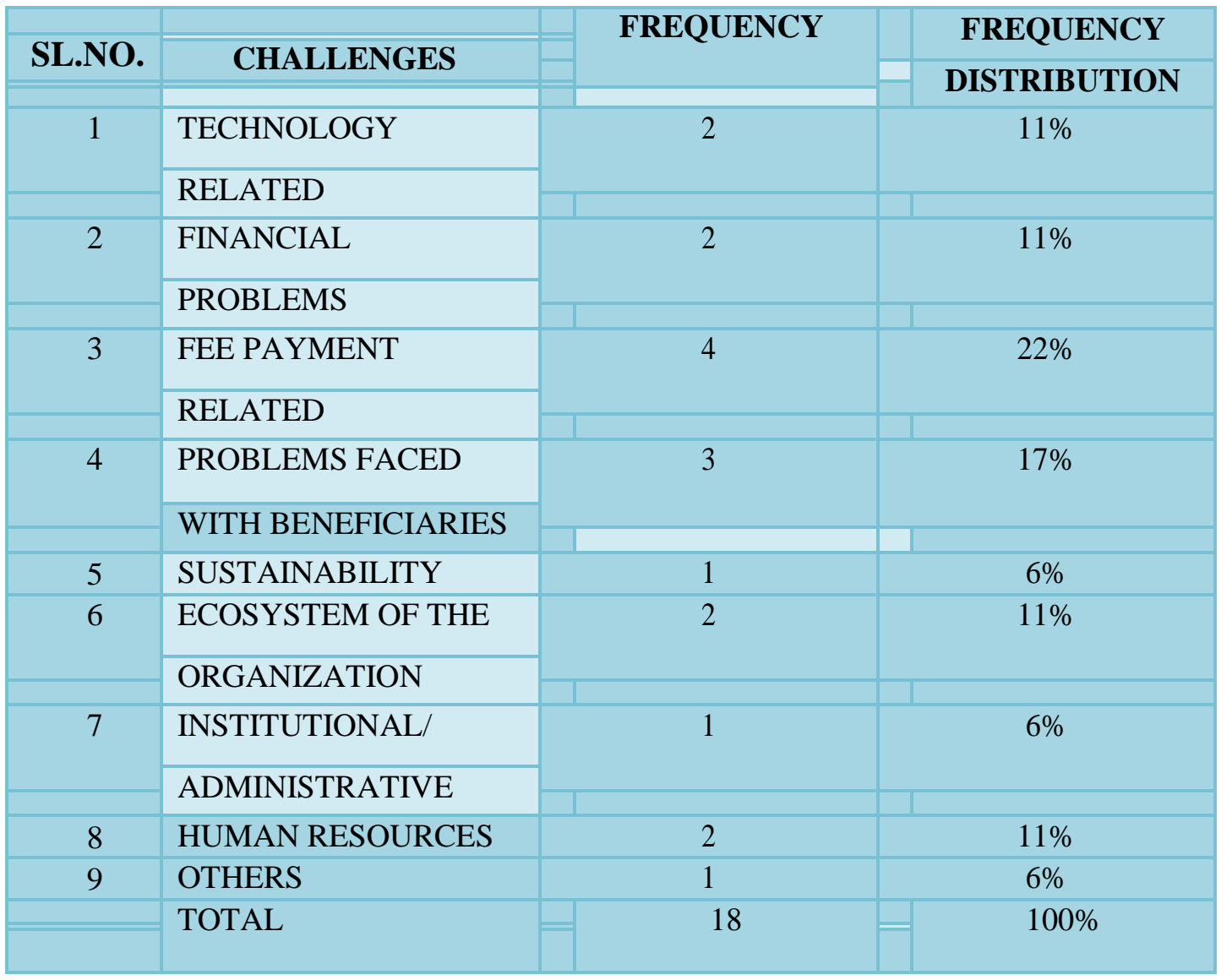

To study the different challenges faced by the Agri Business Incubation centres

Incubation centres play an influential role in the success of the start-ups and entrepreneurs. A Systematic incubator provides all the services that are required for encouraging the start-ups.

In the transit to provide the extensive services to the beneficiaries, incubators encounter through many challenges and they are trying 
to fix the challenges. The illustration shows the challenges faced by the incubators. According to the data collected, table 2 shows the most important challenge faced is fee payment related, which contributes $22 \%$ of the total responses. Most of the incubatees fail to pay the fee or equity to the incubators as they may fail in nascent phase or start-ups doesn't have money to pay them. These types of receivables pose lot of burden on incubation centres.

While sustainability, administrative issues and others like satisfying the beneficiaries plays insignificant role, which contribute $6 \%$ each.

There are also some other challenges faced by the incubation centres such as quality of entrepreneurs, skills possessed by the incubatees, inconsistency in stakeholders, lack of commitment by the stakeholders etc.

Summary and conclusion are as follows:

We have looked into the Agri Business Incubation centres through single aspect majorly, but in two perspectives i.e., challenges faced by the incubatees during the process of incubation and challenges faced by the incubation centres. There were challenges faced by the different stakeholders in ABIs. The different challenges faced by incubatees are technology issues, investment, mentoring process, legal issues and funding process. Technology and investment are major challenges faced by incubatees. Different challenges faced by incubation centres are fee payment issues, investments, sustainability, lack of commitment of stakeholders, support from the government etc. These are the challenges noticed at the basic level of study, in depth study of the Agri Business Incubation centres may understand the challenges/ issues in extensive way. So that the policies or strategies are formed to overcome the challenges and improve the performance of the $\mathrm{ABI}$.

\section{References}

Akcomak, I.S. 2009. Incubators as tools for entrepreneurship promotion in developing countries. United Nations University- World Institute for Development Economics Research. 136. ISBN 978-92-9230-231-3.

Bagchi, N and Chaterjee, K. 2017. Identification of gaps in performance of services provided to start-ups in high technology, low technology and social and agri-business incubation centres in India: Constraints to growth. ASCI Journal of Management. 46: 35-46.

Etela,I and Onoja, O.A. 2017. Incentivizing eAgribusiness Incubators for Youth Employment in Nigeria. Nigerian Agricultural Policy Research Journal. 2(1): 42-54.

Lose, $\mathrm{T}$ and Tengeh, K.R. 2015. The Sustainability and Challenges of Business Incubators in the Western Cape Province, South Africa. Sustainability.7: 14344-14357. ISSN: 2071- 1050. DOI: 10.3390/su71014344.

Meru, A.K and Struwig, M. 2011. An evaluation of the entrepreneurs' perception of Business-Incubation services in Kenya. International Journal of Business Administration. 2(4): 112-121.

NASSCOM. Indian startup ecosystem maturing. 2016. https://www.nasscom.in/knowledgecenter/publications/indian-startecosystem-maturing-2016.

Srinivas, K., Kumar, R., Gerard, M. and Rao, S. 2019. Fostering entrepreneurship in agriculture through incubation centre in National Agricultural Research and Education System. Policy Brief, ICARNAARM. 5: 1-4.

Tengeh, R.K and Choto, P. 2015. The relevance and challenges of business incubators that support survivalist 
entrepreneurs. Investment Management and financial innovations. 12(2): 150161.

Tietz, G., Anholon, R., Ordonez, R.E.C and Quelhas, O.L. 2015. Business
Incubators in Brazil: Main gaps to be explored by Academic Researchers. Journal of technology management and innovation. 10(4): 18-27.

\section{How to cite this article:}

Kadire Preethika, D. Srinivasa Reddy, P. Radhika and Supriya, K. 2020. The Challenges/Issues Faced by Stakeholders of Agri Business Incubation Centres. Int.J.Curr.Microbiol.App.Sci. 9(08): 2503-2509. doi: https://doi.org/10.20546/ijcmas.2020.908.286 